\title{
The Utilization of Pyridine Carbonitriles and Carboxamides by Nocardia rhodochrous LL100-21
}

\author{
By PETER A. VAUGHAN,${ }^{1} \dagger$ PETER S. J. CHEETHAM ${ }^{2} \ddagger$ AND \\ CHRISTOPHER J. KNOWLES ${ }^{1 *}$ \\ ${ }^{1}$ Biological Laboratory, University of Kent, Canterbury, Kent CT2 $7 N J, U K$ \\ ${ }^{2}$ Tate and Lyle Group Research and Development, Philip Lyle Memorial Research Laboratory, \\ PO Box 68, Whiteknights, Reading RG6 2BX, UK
}

(Received 30 December 1987)

Nocardia rhodochrous LL100-21 utilized 2-, 3- or 4-cyanopyridine (2-, 3- or 4-pyridine carbonitrile) and the corresponding pyridine carboxamides as sources of nitrogen for growth. Studies with intact bacteria and cell-free extracts indicated that 3-cyanopyridine was hydrolysed directly to nicotinic acid by an inducible 3-cyanopyridinase enzyme (a nitrilase), and that the organism also possessed a separately inducible nicotinamidase. In cultures supplied with 3cyanopyridine or nicotinamide as the source of nitrogen the compounds were hydrolysed to form ammonia, which was utilized for growth, and nicotinic acid, which was not further metabolized and accumulated in the culture medium. In cultures containing 3-cyanopyridine, which had a bacteriostatic effect, little growth occurred until all the nitrile had been converted to nicotinic acid; the specific activity of 3-cyanopyridinase of the bacteria was highest in the early exponential phase of growth and had disappeared by the stationary phase. Measurements of the abilities to either oxidize or release ammonia from heterocyclic, aromatic and aliphatic nitriles and amides by bacteria grown on the various substrates indicated that benzonitrile acted as both a substrate and an inducer of 3-cyanopyridinase activity, whereas benzamide acted as a substrate and an inducer of nicotinamidase. These enzymes are induced separately from the acetonitrile hydratase/acetamidase enzyme system of this bacterium.

\section{INTRODUCTION}

The utilization of nitriles by micro-organisms normally involves an initial hydrolysis of the nitrile group to the corresponding acid plus ammonia (Jallageas et al., 1980; Chamberlin \& MacKenzie, 1981). Nocardia rhodochrous LL100-21 can grow on a range of aliphatic nitriles and amides, as well as benzonitrile and benzamide, as sources of carbon and/or nitrogen. Aliphatic nitriles were found to be catabolized in two stages, via conversion to the corresponding amide and then to the carboxylic acid plus ammonia, by a nitrile hydratase and an amidase respectively. The two enzymes were co-induced by either aliphatic nitriles or amides (DiGeronimo \& Antoine, 1976; Collins \& Knowles, 1983; Linton \& Knowles, 1986).

Studies by Collins \& Knowles (1983) indicated that the utilization of benzonitrile and benzamide by $N$. rhodochrous LL100-21 involved different enzymes to those responsible for aliphatic nitrile or amide hydrolysis. It appeared that benzonitrile was probably converted directly to benzoic acid plus ammonia by a single, inducible nitrilase without formation of an amide as an intermediate, as has been demonstrated for the utilization of benzonitrile by Nocardia sp. NCIB 11216 and Fusarium solani (Harper, 1976, 1977a,b) and 4-hydroxybenzo\footnotetext{
UK.

$\dagger$ Present address: Genetics International (UK) Inc., 38 Nuffield Way, Abingdon, Oxfordshire OX14 1RL,

$\ddagger$ Present address: QUEST International Ltd, Ashford, Kent TN24 0LT, UK.
} 
nitrile by Nocardia sp. NCIB 11215 (Harper, 1985). The utilization of benzamide by $N$. rhodochrous LL100-21 appeared to involve a separately induced benzamidase (Collins \& Knowles, 1983).

In the present study we have investigated the utilization of pyridine carbonitriles and carboxamides by $N$. rhodochrous LL100-21. In particular, we have studied the utilization of 3cyanopyridine (3-pyridine carbonitrile) in order to assess whether the bacterium was a suitable candidate for use as a biocatalyst for the conversion of the nitrile to the vitamin nicotinic acid (3pyridine carboxylic acid).

\section{METHODS}

Organism and growth conditions. Nocardia rhodochrous strain LL100-21 was grown on a minimal medium consisting of M9 salts (Miller, 1972) with ammonium salts omitted, $1 \mathrm{ml}$ trace metals 1 $^{-1}$ (Bauchop \& Elsden, 1960) plus carbon and nitrogen sources. Growth was in either $100 \mathrm{ml}$ medium in $250 \mathrm{ml}$ conical flasks or $500 \mathrm{ml}$ medium in 21 conical flasks. Incubation was at $30^{\circ} \mathrm{C}$ in an orbital shaker.

The following compounds were tested for their ability to support growth: 2-, 3- and 4-cyanopyridine, the corresponding pyridine carboxamides and pyridine carboxylic acids, and 3-pyridylacetonitrile. Each was tested as carbon and nitrogen source $(6 \mathrm{~mm})$, carbon source $\left(6 \mathrm{~mm}\right.$ plus $\left.2 \mathrm{~mm}-\mathrm{NH}_{4} \mathrm{Cl}\right)$, and nitrogen source $(2 \mathrm{mM}$ plus $20 \mathrm{~mm}$-acetate). Flasks were inoculated with a $2 \%(\mathrm{v} / \mathrm{v})$ inoculum of a 20 to $24 \mathrm{~h}$ stationary phase culture grown on $20 \mathrm{~mm}$-acetate plus $2 \mathrm{mM}-\mathrm{NH}_{4} \mathrm{Cl}$. Growth was indicated by the test cultures attaining an $\mathrm{OD}_{600}$ of at least $0 \cdot 7$ after $96 \mathrm{~h}$, and no growth by an $\mathrm{OD}_{600}$ of less than $0 \cdot 1120 \mathrm{~h}$ after inoculation.

For other studies the carbon and nitrogen sources were acetate $(20 \mathrm{mM})$ plus 3-cyanopyridine $(2 \mathrm{~mm})$, benzoate $(6 \mathrm{mM})$ plus 3-cyanopyridine $(2 \mathrm{mM})$, acetate $(20 \mathrm{~mm})$ plus nicotinamide (3-pyridine carboxamide) $(2 \mathrm{~mm})$, benzoate $(6 \mathrm{mM})$ plus nicotinamide $(2 \mathrm{mM})$, benzonitrile $(6 \mathrm{mM})$, benzamide $(6 \mathrm{~mm})$, acetonitrile $(20 \mathrm{mM})$, acetamide $(20 \mathrm{mM})$, acetate $(20 \mathrm{mM})$ plus $\mathrm{NH}_{4} \mathrm{Cl}(2 \mathrm{mM})$, benzoate $(6 \mathrm{mM})$ plus $\mathrm{NH}_{4} \mathrm{Cl}(2 \mathrm{mM})$. Experimental flasks were inoculated with a $2 \%(\mathrm{v} / \mathrm{v})$ inoculum of a stationary phase culture grown on the same carbon and nitrogen sources as the experimental flask. Inoculum cultures containing nicotinamide were grown for $72 \mathrm{~h}$ before use (the time taken to achieve stationary phase); for other inoculum cultures 20 to $24 \mathrm{~h}$ was sufficient.

Harvesting and preparation of cell-free extracts. Cultures were harvested by centrifugation at $23000 \mathrm{~g}$ for $10 \mathrm{~min}$ at $4{ }^{\circ} \mathrm{C}$, washed with $50 \mathrm{~mm}$-sodium phosphate buffer $(\mathrm{pH} \mathrm{7.0)}$ ) and resuspended in fresh buffer to about $2 \%$ of the original culture volume.

Cell-free extracts were prepared using bacteria harvested in the mid-exponential phase of culture growth (culture $\mathrm{OD}_{600} 0 \cdot 3$ to $0 \cdot 6$ ). Bacteria were disrupted by sonication (MSE sonicator, $150 \mathrm{~W}, 2 \times 15 \mathrm{~s}$ ) at 18 to $22^{\circ} \mathrm{C}$ (room temperature). The vial was surrounded by a water-jacket through which water at room temperature was pumped. The resulting suspension was centrifuged at $15000 \mathrm{~g}$ for $10 \mathrm{~min}$ at $22{ }^{\circ} \mathrm{C}$, to produce a clear cell-free extract.

Determination of respiratory activity. The bacteria used in oxygen uptake studies were harvested in the midexponential phase of culture growth ( $\mathrm{OD}_{600} 0 \cdot 3$ to $\left.0 \cdot 6\right)$. Oxygen uptake by intact bacteria was measured at $30^{\circ} \mathrm{C}$ with an oxygen electrode (Rank). The incubation mixture contained $0 \cdot 1$ to $0.2 \mathrm{mg}$ dry wt bacteria in $50 \mathrm{~mm}$-sodium phosphate buffer ( $\mathrm{pH} \mathrm{7.0)}$ ), in a total volume of $2.9 \mathrm{ml}$. The reaction was initiated by the addition of $0.1 \mathrm{ml}$ of $150 \mathrm{~mm}$ substrate. In the case of benzonitrile or benzamide, which are of low solubility in water, the reaction was initiated by adding $0.1 \mathrm{ml}$ bacterial suspension to $2.9 \mathrm{ml}$ buffer containing $5.2 \mathrm{~mm}$ substrate.

Ammonia assay. The method used was based on that of Fawcett \& Scott (1960). To a sample ( $0 \cdot 5 \mathrm{ml})$ containing up to $200 \mu \mathrm{M}$-ammonia $0.5 \mathrm{ml}$ nitroprusside reagent $(0.106 \mathrm{M}$-phenol containing $0.17 \mathrm{~mm}$-sodium nitroprusside) was added, followed by $0.5 \mathrm{ml}$ alkaline hypochlorite reagent $(0.125 \mathrm{M}$-sodium hydroxide containing $11 \mathrm{~mm}$-sodium hypochlorite). The mixture was incubated at $70^{\circ} \mathrm{C}$ for $15 \mathrm{~min}$ and the $A_{570}$ was measured. In samples containing 3-cyanopyridine, nicotinamide or nicotinic acid the final $A_{570}$ of the assay mixture was lower, but the relationship between $A_{570}$ and ammonia concentration remained linear. The effect on the assay was the same for each of these compounds and the reduction in $A_{570}$ was related to the total concentration of these compounds present in the sample being assayed.

Acetate assay. Acetate was assayed by GLC as described previously (Collins \& Knowles, 1983).

Determination of 3-cyanopyridine, nicotinamide and nicotinic acid by reversed phase HPLC. The HPLC system consisted of a Laboratory Data Control/Milton Roy (Stone, Staffordshire, UK) contantimetric IIIG solvent delivery pump, spectromonitor IIIG variable wavelength absorbance detector, CI-10 computing integrator and a model SEK printer plotter. The column was a $250 \times 4.6 \mathrm{~mm}$ inside diameter Hplc Technology Ltd (Macclesfield, Cheshire, UK) spherisorb $5 \mu$ ODS $\left(\mathrm{C}_{18}\right)$ reversed phase column. The solvent was water/methanol/propan-2-ol (155:44:1, by vol.), containing $10 \cdot 2 \mathrm{mM}$-phosphoric acid and $10 \mathrm{~mm}$-tetramethylammonium hydroxide (which acts as a counter-ion), pumped at $1.3 \mathrm{ml} \mathrm{min}^{-1}$. Compounds were detected by the absorbance at $220 \mathrm{or} 262 \mathrm{~nm}$. A sample $(0.2 \mathrm{ml})$ containing up to $5 \mathrm{~mm}$-3-cyanopyridine, nicotinamide or nicotinic acid, was mixed with $50 \mu \mathrm{l}$ 
20 mM-picolinamide (2-pyridine carboxamide), which acted as an internal standard, and $20 \mu l$ of the mixture was injected into the HPLC system via a Rheodyne model 7125 syringe loading sample injector valve.

Determination of metabolites in the growth medium. Samples $(2 \mathrm{ml})$ were aseptically removed from cultures and centrifuged for $2 \mathrm{~min}$ at $13000 \mathrm{~g}$ in a MicroCentaur bench centrifuge (MSE). From the supernatant three $400 \mu \mathrm{l}$ samples were removed and stored at $-20^{\circ} \mathrm{C}$ until required for GLC, HPLC or ammonia analysis.

Determination of nitrilase and amidase activities. Nitrilase and amidase were measured by ammonia release. The reaction mixture ( 2 to $10 \mathrm{ml}$ ) at $30^{\circ} \mathrm{C}$ contained $50 \mathrm{~mm}$-sodium phosphate buffer (pH 7.0), $5 \mathrm{mM}$ nitrile or amide,

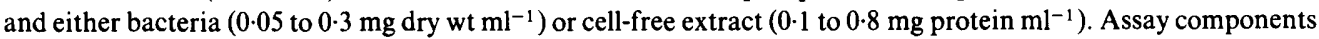
were pre-incubated for $10 \mathrm{~min}$ at $30^{\circ} \mathrm{C}$ before the reaction was initiated by the addition of substrate. Samples of the reaction mixture were removed at intervals for 30 to $60 \mathrm{~min}$. For intact bacteria, samples ( $1 \mathrm{ml}$ ) were removed, centrifuged for $1 \mathrm{~min}$ at $13000 \mathrm{~g}$ in a MicroCentaur centrifuge and $0.5 \mathrm{ml}$ of the supernatant was added to $0.5 \mathrm{ml}$ nitroprusside reagent for assay of ammonia. For assays using cell-free extracts, samples of the reaction mixture were either added directly to nitroprusside reagent, or, if necessary, first diluted with buffer.

Collins \& Knowles (1983) showed that acetamidase activity of $N$. rhodochrous LL100-21 is lower than the acetonitrile hydratase activity and therefore measurement of ammonia release from acetonitrile is not a quantitative measurement of acetonitrile hydratase activity.

Determination of the products of 3-cyanopyridine hydrolysis by cell-free extracts. A reaction mixture $(9 \mathrm{ml})$ at $30^{\circ} \mathrm{C}$ was prepared containing $5 \mathrm{mM}$-3-cyanopyridine in $50 \mathrm{~mm}$-sodium phosphate buffer $(\mathrm{pH} 7.0)$ and cell-free extract $\left(0.8 \mathrm{mg}\right.$ protein $\left.\mathrm{ml}^{-1}\right)$ derived from bacteria grown on 3-cyanopyridine as the sole nitrogen source. Two samples $(0.1$ and $0.9 \mathrm{ml})$ of the reaction mixture were removed at regular intervals. The $0.1 \mathrm{ml}$ sample was mixed with $1.9 \mathrm{ml} 50 \mathrm{~mm}$-sodium phosphate buffer $(\mathrm{pH} 7.0)$ and $0.5 \mathrm{ml}$ of the mixture was added to $0.5 \mathrm{ml}$ nitroprusside reagent for assay of ammonia. The $0.9 \mathrm{ml}$ sample was mixed with $0.1 \mathrm{ml}$ of $25 \%(\mathrm{w} / \mathrm{v})$ trichloroacetic acid. The mixture was kept on ice for $2 \mathrm{~h}$ and then centrifuged for $2 \mathrm{~min}$ at $13000 \mathrm{~g}$ in a bench centrifuge to remove the precipitated protein. A sample $(0.5 \mathrm{ml})$ of the supernatant was mixed with $50 \mu 11.53 \mathrm{M}$-sodium hydroxide to neutralize the trichloroacetic acid. The neutralized sample was stored at $-20^{\circ} \mathrm{C}$ until required for $\mathrm{HPLC}$ analysis. The protein precipitation and neutralization procedure did not cause any breakdown of 3-cyanopyridine, nicotinamide or nicotinic acid when tested with standard solutions.

Other assays. Protein was measured by the modified biuret method of Gornall et al. (1969). Bacterial growth was measured as the $\mathrm{OD}_{600}$ using an LKB Ultraspec spectrophotometer.

Chemicals. 3-Cyanopyridine, nicotinamide, nicotinic acid, isonicotinamide (4-pyridine carboxamide), benzamide, sodium benzoate, acetonitrile and acetamide were obtained from Sigma. 2-Cyanopyridine (2-pyridine carbonitrile), 4-cyanopyridine (4-pyridine carbonitrile), picolinamide, picolinic acid (2-pyridine carboxylic acid), isonicotinic acid (4-pyridine carboxylic acid) and 3-pyridylacetonitrile were obtained from Aldrich. Benzonitrile was obtained from BDH. 3-Cyanopyridine was recrystallized from hot water, nicotinamide was recrystallized from hot propan-2-ol, and acetamide and benzamide were recrystallized from hot ethanol. Whenever possible, all other reagents were of analytical grade. Glass distilled water was used throughout this work.

\section{RESULTS AND DISCUSSION}

\section{Utilization of pyridine carbonitriles, carboxamides and carboxylic acids as carbon and nitrogen sources for growth}

$N$. rhodochrous LL100-21 was found to be able to grow on 2-, 3- or 4-cyanopyridine and the corresponding pyridine carboxamides as sources of nitrogen for growth, but not as sources of carbon; the corresponding pyridine carboxylic acids were not utilized for growth. 3Pyridylacetonitrile could also be utilized as a nitrogen source. These findings contrast with the observations of Collins \& Knowles (1983) that the aromatic compounds benzonitrile and benzamide could each support growth of $N$. rhodochrous LL100-21 as sole carbon and nitrogen source, and that benzoic acid could act as a carbon source for growth but phenylacetonitrile could not be utilized.

\section{Hydrolysis of amides and nitriles by intact bacteria}

The ability of bacteria to release ammonia from aliphatic, aromatic and heterocyclic nitriles and amides is shown in Table 1. The aliphatic nitrile hydratase/amidase system induced by growth on acetonitrile or acetamide did not hydrolyse the aromatic or heterocyclic amides or nitriles to release ammonia. Since growth on either 3-cyanopyridine or benzonitrile induced the ability to release ammonia from both nitriles, both 3-cyanopyridine and benzonitrile were probably hydrolysed by the same inducible enzyme system. This was more likely to be a nitrilase 
Table 1. Effect of growth substrate on ammonia release from aromatic, heterocyclic and aliphatic nitriles and amides by $N$. rhodochrous LL100-21

Ammonia release was measured using intact bacteria harvested in the mid-exponential phase of culture growth (culture $\mathrm{OD}_{600} 0 \cdot 3$ to $0 \cdot 6$ ). There was no detectable release of ammonia from harvested bacteria in the absence of substrate, nor was there release of ammonia from any of the substrates in the absence of bacteria.

\begin{tabular}{|c|c|c|c|c|c|c|}
\hline \multirow[b]{3}{*}{ Growth substrate } & \multicolumn{6}{|c|}{ Ammonia released $\left[\mathrm{nmol} \min ^{-1}(\mathrm{mg} \text { dry } w t)^{-1}\right]$} \\
\hline & & & bstrate added & $(5 \mathrm{~mm}):$ & & \\
\hline & 3-Cyanopyridine & Nicotinamide & Benzonitrile & Benzamide & Acetonitrile & Acetamide \\
\hline $\begin{array}{l}\text { 3-Cyanopyridine } \\
\text { + acetate }\end{array}$ & 52 & 0 & 36 & 1 & 0 & 1 \\
\hline $\begin{array}{l}\text { 3-Cyanopyridine } \\
\text { + benzoate }\end{array}$ & 13 & 1 & 5 & 0 & 1 & 1 \\
\hline $\begin{array}{l}\text { Nicotinamide } \\
+ \text { acetate }\end{array}$ & 29 & 29 & 26 & 35 & 17 & 26 \\
\hline $\begin{array}{l}\text { Nicotinamide } \\
+ \text { benzoate }\end{array}$ & 12 & 14 & 15 & 20 & 1 & 4 \\
\hline Benzonitrile & 84 & 1 & 40 & 0 & 1 & 1 \\
\hline Benzamide & 12 & 20 & 18 & 32 & 1 & 3 \\
\hline Acetonitrile & 0 & 0 & 0 & 0 & 290 & 292 \\
\hline Acetamide & 0 & 0 & 0 & 0 & 382 & 258 \\
\hline $\mathrm{NH}_{4} \mathrm{Cl}+$ acetate & 0 & 0 & 0 & 0 & 0 & 0 \\
\hline $\mathrm{NH}_{4} \mathrm{Cl}+$ benzoate & 0 & 0 & 0 & 0 & 0 & 0 \\
\hline $\mathrm{NH}_{4} \mathrm{Cl}+$ acetate & 0 & 0 & 0 & 0 & 0 & 0 \\
\hline
\end{tabular}

Table 2. Effect of growth substrate on $\mathrm{O}_{2}$ uptake by $N$. rhodochrous LL100-2I

Values for $\mathrm{O}_{2}$ uptake are for initial rates except for benzamide and benzonitrile where there was an initial lag prior to initial $\mathrm{O}_{2}$ uptake. NT, not tested.

\begin{tabular}{|c|c|c|c|c|c|c|c|c|c|}
\hline \multirow[b]{2}{*}{$\begin{array}{l}\text { Growth } \\
\text { substrate }\end{array}$} & \multicolumn{9}{|c|}{$\mathrm{O}_{2}$ uptake [ng-atom $\left.\min ^{-1}(\mathrm{mg} \text { dry } w t)^{-1}\right]$} \\
\hline & $\begin{array}{l}\text { 3-Cyano- } \\
\text { pyridine }\end{array}$ & $\begin{array}{l}\text { Nicotin- } \\
\text { amide }\end{array}$ & $\begin{array}{l}\text { Nicotinic } \\
\text { acid }\end{array}$ & $\begin{array}{c}\text { Substrate } \\
\text { Benzo- } \\
\text { nitrile }\end{array}$ & $\begin{array}{l}\text { e added } \\
\text { Benz- } \\
\text { amide }\end{array}$ & $\begin{array}{c}(5 \mathrm{~mm}) \\
\text { Benzoic } \\
\text { acid }\end{array}$ & $\begin{array}{l}\text { Aceto- } \\
\text { nitrile }\end{array}$ & Acetamide & Acetate \\
\hline $\begin{array}{l}\text { 3-Cyanopyridine } \\
\text { + acetate }\end{array}$ & 0 & 0 & 0 & 7 & 6 & 0 & 0 & 2 & 82 \\
\hline $\begin{array}{l}\text { 3-Cyanopyridine } \\
\text { + benzoate }\end{array}$ & 0 & 0 & 0 & 94 & 22 & 66 & 0 & 2 & 7 \\
\hline $\begin{array}{l}\text { Nicotinamide }+ \\
\text { acetate }\end{array}$ & NT & 4 & 2 & 0 & 1 & 0 & 19 & 31 & 160 \\
\hline $\begin{array}{l}\text { Nicotinamide } \\
\text { + benzoate }\end{array}$ & 1 & 0 & 3 & 49 & 65 & 77 & 1 & 3 & 3 \\
\hline $\mathrm{NH}_{4} \mathrm{Cl}+$ acetate & 1 & 1 & 0 & 0 & 0 & 1 & 0 & 2 & 95 \\
\hline $\mathrm{NH}_{4} \mathrm{Cl}+$ benzoate & 0 & 0 & 0 & 2 & 10 & 50 & 3 & 0 & 0 \\
\hline
\end{tabular}

that was able to hydrolyse 3-cyanopyridine and benzonitrile directly to the corresponding carboxylic acids rather than a two-enzyme nitrile hydratase plus amidase system, as neither nitrile induced any nicotinamidase or benzamidase activity. The results in Table 1 also suggest that growth on nicotinamide or benzamide resulted in the induction of a single amidase which hydrolysed both amides to the corresponding carboxylic acids, as well as causing co-induction of the 3-cyanopyridine/benzonitrile nitrilase. Another possibility is that 3-cyanopyridine and benzonitrile act as substrates for the amidase.

Oxidation of nitriles, amides and carboxylic acids by intact bacteria

The rates of respiration by intact harvested bacteria that had been grown under various conditions are shown in Table 2. N. rhodochrous LL100-21 appeared to have little ability to 


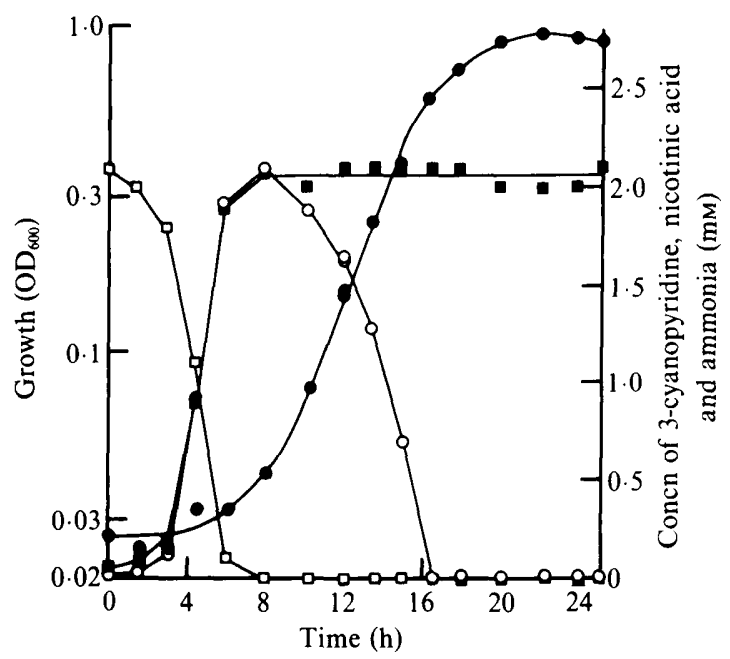

Fig. 1. $N$. rhodochrous LL100-21 was grown on $20 \mathrm{~mm}$-acetate $+2 \mathrm{mM}$-3-cyanopyridine. Growth was measured as $\mathrm{OD}_{600}(O)$. The ammonia concentration $(O)$ in the medium was measured colorimetrically; 3-cyanopyridine $(\square)$ and nicotinic acid ( $\square$ ) were determined by HPLC. No nicotinamide was detected at any time. Two cultures staggered by $12 \mathrm{~h}$ were used to obtain the growth curve and metabolite measurements.

oxidize nicotinic acid, 3-cyanopyridine or nicotinamide. Bacteria grown on 3-cyanopyridine as the nitrogen source plus benzoate as the carbon source oxidized benzoate at a similar rate to bacteria grown on benzoate plus ammonia, but could oxidize benzonitrile at a very much greater rate. This is consistent with the induction of a nitrilase able to hydrolyse benzonitrile to benzoate during growth on 3-cyanopyridine. Bacteria grown on benzoate plus 3-cyanopyridine or ammonia also had some ability to oxidize benzamide but did not release ammonia from this compound (Table 1), possibly because the bacteria oxidized benzamide by a route not involving hydrolysis to benzoic acid. Bacteria grown on nicotinamide plus benzoate oxidized benzoate at a similar rate to bacteria grown on benzoate plus ammonia, but could oxidize both benzonitrile and benzamide at greater rates; this is consistent with nicotinamide inducing the ability to hydrolyse both benzonitrile and benzamide to nicotinic acid. Collins \& Knowles (1983) observed an initial lag in the rate of oxidation of benzonitrile and benzamide by benzamide- or benzonitrile-grown bacteria. This was also observed in this study for the oxidation of these substrates by bacteria grown on 3-cyanopyridine or nicotinamide as the nitrogen source.

Interpretation of experiments using intact bacteria could be complicated by the existence of inducible uptake systems for the various nitriles and amides, necessary for the hydrolysis of these compounds by intracellular enzymes. Little is known about the translocation of amides and nitriles into bacteria. Farin (quoted by Clarke, 1980) suggested that uptake of acetamide by Pseudomonas aeruginosa was by passive diffusion, and Miller \& Knowles (1984) concluded that entry of acetamide and acetonitrile into Brevibacterium R312 was probably by simple diffusion. It would seem probable, however, that the much larger heterocyclic and aromatic nitriles and amides would enter and leave bacteria by transport systems; evidence for nicotinamide transport systems in Escherichia coli and Bordetella pertussis has been reported (Griffith \& Leach, 1973; McPheat \& Wardlaw, 1982; McPheat et al., 1983).

Changes in culture metabolites and 3-cyanopyridinase activity during growth on 3-cyanopyridine

Growth of $N$. rhodochrous LL100-21 on $20 \mathrm{~mm}$-acetate plus $2 \mathrm{~mm}$-3-cyanopyridine and the changes in concentrations of metabolites in the culture medium are shown in Fig. 1. Little growth occurred until the 3-cyanopyridine had disappeared from the culture medium. The decline in the 3-cyanopyridine concentration was accompanied by accumulation of nicotinic 
Table 3. 3-Cyanopyridinase activity of $N$. rhodochrous LL100-21 during growth on $20 m \mathrm{~m}$-acetate $+2 m \mathrm{~m}$-3-cyanopyridine

$N$. rhodochrous LL100-21 was grown on $20 \mathrm{~mm}$-acetate $+2 \mathrm{~mm}$-3-cyanopyridine and harvested at various times after inoculation. The 3-cyanopyridinase specific activities of the intact harvested bacteria were determined using the ammonia release assay. The concentration of bacteria in cultures at various $\mathrm{OD}_{600}$ values was estimated by assuming that $1 \mathrm{OD}_{600}$ unit was equivalent to $0.41 \mathrm{mg}$ dry wt bacteria $\mathrm{ml}^{-1}$, and from this the total 3-cyanopyridinase activity in the culture was calculated.

\begin{tabular}{|c|c|c|c|}
\hline $\begin{array}{l}\text { Culture } \\
\text { growth } \\
\text { time (h) }\end{array}$ & $\begin{array}{l}\text { Culture } \\
\text { OD }_{600}\end{array}$ & $\begin{array}{l}\text { Specific activity of } \\
\text { 3-cyanopyridinase } \\
\text { [nmol min }{ }^{-1} \\
(\mathrm{mg} \mathrm{dry} \mathrm{wt} \\
\left.\text { bacteria })^{-1}\right]\end{array}$ & $\begin{array}{c}\text { Total } \\
\text { 3-cyanopyridinase } \\
\text { activity } \\
{\left[\text { nmol min }{ }^{-1}\right.} \\
\left.(\mathrm{ml} \text { culture })^{-1}\right]\end{array}$ \\
\hline $0 \cdot 0$ & 0.030 & 0 & 0 \\
\hline 4.0 & 0.033 & 330 & 4.6 \\
\hline $6 \cdot 4$ & 0.047 & 470 & 8.9 \\
\hline $9 \cdot 8$ & 0.092 & 150 & $5 \cdot 6$ \\
\hline $12 \cdot 8$ & $0 \cdot 360$ & 52 & $7 \cdot 8$ \\
\hline $16 \cdot 2$ & 0.612 & 13 & $3 \cdot 3$ \\
\hline 24.0 & 0.897 & 0 & 0 \\
\hline $30 \cdot 2$ & 0.855 & 0 & 0 \\
\hline
\end{tabular}

acid and ammonia in the culture medium equivalent to the initial concentration of 3cyanopyridine. The ammonia was used for growth but the nicotinic acid persisted in the culture medium. No nicotinamide was detected at any time. In a separate culture grown on the same substrates, measurements of the acetate concentration in the culture medium showed that growth terminated at the time the acetate became exhausted.

In cultures grown on $20 \mathrm{~mm}$-acetate plus $2 \mathrm{~mm}$-3-cyanopyridine the specific activity of 3cyanopyridinase measured in intact bacteria was zero at the time of culture inoculation and peaked during the early exponential phase of growth (Table 3 ). The specific activity decreased to zero by the end of growth. Calculations of the approximate total 3-cyanopyridinase activity (per $\mathrm{ml}$ of culture) at different stages of culture growth (Table 3 ) indicate that the decline in specific activity of 3-cyanopyridinase (after the early exponential phase) was largely due to dilution of activity by bacterial growth with little inactivation or loss of activity. This suggests that synthesis and/or activation of the 3-cyanopyridinase ceased after the early exponential phase of growth, i.e. after 3-cyanopyridine had disappeared from the culture medium, and that complete loss or inactivation of 3-cyanopyridinase activity did not occur until later, around the end of the growth period. No nicotinamidase activity was detected at any stage of culture growth.

The observation that in a culture containing $2 \mathrm{~mm}-3$-cyanopyridine, little growth occurred until the nitrile had disappeared, suggested that 3-cyanopyridine was bacteriostatic for $N$. rhodochrous LL100-21. To investigate this further the organism was grown in a medium containing $10 \mathrm{mM}$-3-cyanopyridine plus $20 \mathrm{~mm}$-acetate, where there was an increase in the lag period before growth commenced. Measurements of the concentrations of the appropriate compounds in the growth medium showed that 3-cyanopyridine hydrolysis occurred throughout the extended lag period and again little growth occurred until the 3-cyanopyridine was exhausted. The presence of an additional $2 \mathrm{~mm}$-ammonium at the time of inoculation of such a culture did not shorten the lag period or affect the time course of 3-cyanopyridine hydrolysis, confirming that it was the presence of 3-cyanopyridine that inhibited growth. There is evidence that other nitriles may be bacteriostatic for certain bacteria. Harper (1977a) found that a culture of Nocardia sp. NCIB 11216 supplied with benzonitrile showed little growth until all the benzonitrile had been hydrolysed. Arthrobacter I-9 could utilize acrylonitrile as the sole source of carbon and nitrogen for growth. Increasing the initial concentration of acrylonitrile in cultures of this organism extended the lag period (Yamada et al., 1979). 


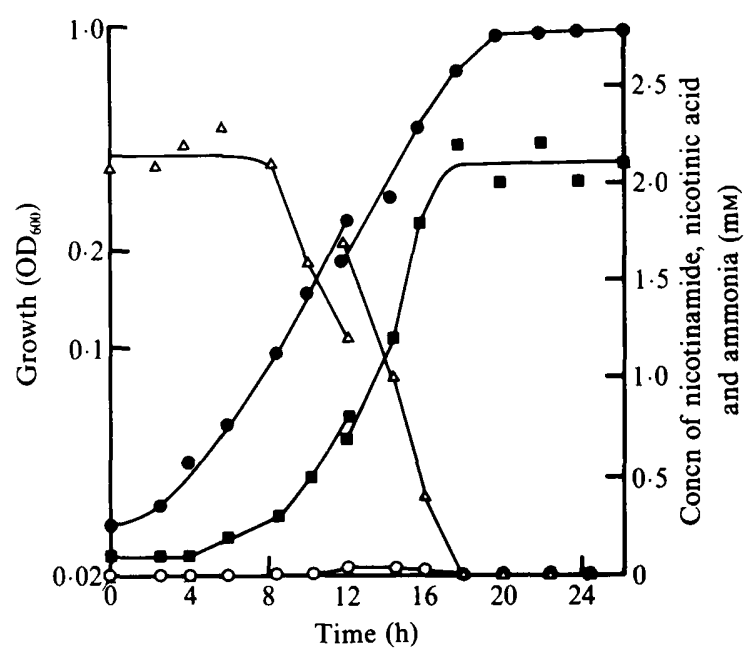

Fig. 2. $N$. rhodochrous LL100-21 was grown on $20 \mathrm{~mm}$-acetate $+2 \mathrm{~mm}$-nicotinamide. Growth was measured as $\mathrm{OD}_{600}(\mathrm{O})$. The ammonia concentration $(\mathrm{O})$ in the medium was measured colorimetrically; nicotinamide $(\triangle)$ and nicotinic acid $(\boldsymbol{D})$ were determined by HPLC. Two cultures staggered by $12 \mathrm{~h}$ were used to obtain the measurements.

Table 4. Nicotinamidase and 3-cyanopyridinase activities of $N$. rhodochrous LL100-21 during growth on $20 \mathrm{mM}$-acetate $+2 \mathrm{mM}$-nicotinamide

$N$. rhodochrous LL100-21 was grown on 20 mM-acetate +2 mM-nicotinamide and harvested at various times after inoculation. The nicotinamidase and 3-cyanopyridinase activities of the harvested bacteria were determined using the ammonia release assay.

\begin{tabular}{|c|c|c|c|}
\hline \multirow{2}{*}{$\begin{array}{l}\text { Culture } \\
\text { growth } \\
\text { time (h) }\end{array}$} & \multirow{2}{*}{$\begin{array}{l}\text { Culture } \\
\mathrm{OD}_{600}\end{array}$} & \multicolumn{2}{|c|}{$\begin{array}{l}\text { Specific enzyme activity } \\
\left.\text { [nmol } \min ^{-1}(\mathrm{mg} \text { dry wt bacteria })^{-1}\right]\end{array}$} \\
\hline & & Nicotinamidase & 3-Cyanopyridinase \\
\hline $0 \cdot 0$ & 0.025 & 15 & 17 \\
\hline $5 \cdot 4$ & 0.052 & 15 & 15 \\
\hline 6.0 & 0.056 & 11 & 11 \\
\hline $12 \cdot 0$ & $0 \cdot 163$ & 11 & 8 \\
\hline $14 \cdot 4$ & 0.507 & 29 & 29 \\
\hline $15 \cdot 6$ & 0.528 & 38 & 36 \\
\hline $17 \cdot 6$ & 0.586 & 47 & 49 \\
\hline $24 \cdot 0$ & $0 \cdot 860$ & 16 & 16 \\
\hline $30 \cdot 2$ & 0.850 & 4 & 4 \\
\hline
\end{tabular}

\section{Changes in culture metabolites, and nicotinamidase and 3-cyanopyridinase activities during} growth on nicotinamide

In a culture grown on $2 \mathrm{~mm}$-nicotinamide plus $20 \mathrm{~mm}$-acetate the nicotinamide did not become exhausted until near the end of the growth period and there was no evidence that nicotinamide inhibited growth of the organism (Fig. 2). As the nicotinamide concentration fell, nicotinic acid accumulated in the culture medium to an equivalent concentration. No further metabolism of the nicotinic acid was observed. Little free ammonia appeared in the culture medium during growth, which ceased when acetate was exhausted.

In these cultures nicotinamidase activity was present in intact bacteria throughout growth and persisted into the stationary phase (Table 4). The nicotinamidase activity present at the time of inoculation of the experimental culture presumably resulted from induction of nicotinamidase activity during growth of the inoculum culture on $20 \mathrm{mM}$-acetate plus $2 \mathrm{~mm}$-nicotinamide. The 


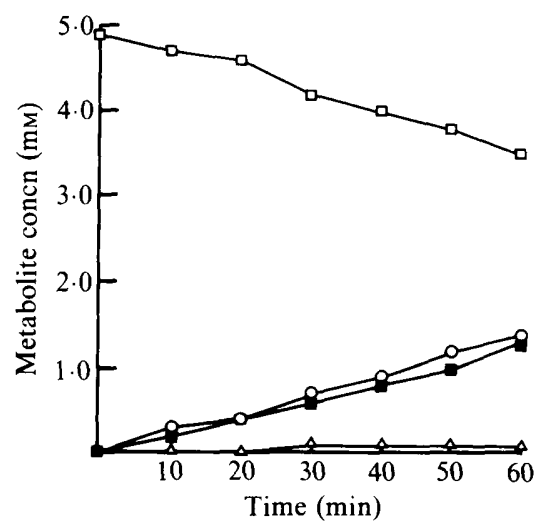

Fig. 3. Cell-free extract from $N$. rhodochrous LL100-21 grown on $20 \mathrm{~mm}$-acetate $+2 \mathrm{~mm}-3-$ cyanopyridine to mid-exponential phase, was incubated with 3-cyanopyridine ( $\square$ ). Nicotinic acid ( $\square$ ), nicotinamide $(\triangle)$ and ammonia $(O)$ were assayed as described in Methods.

specific activity of nicotinamidase measured in intact bacteria was maximal in the late exponential phase of growth (Table 4). At each stage of culture growth 3-cyanopyridinase activity was present at approximately the same specific activity as the nicotinamidase activity.

\section{Studies with cell-free extracts}

Cell-free extracts derived from bacteria grown on 3-cyanopyridine as the nitrogen source

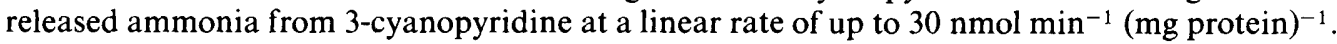
Ammonia was released from benzonitrile at approximately the same rate as from 3cyanopyridine, but the rates of ammonia release from nicotinamide or benzamide were less than $1 \mathrm{nmol} \mathrm{min}{ }^{-1}$ (mg protein $)^{-1}$. The 3-cyanopyridinase activity in cell-free extracts was very labile and also cold sensitive, so the extracts were prepeared at 18 to $22^{\circ} \mathrm{C}$ (room temperature). Approximately $60 \%$ of the initial 3-cyanopyridinase activity was lost during storage for $2 \mathrm{~h}$ at $4{ }^{\circ} \mathrm{C}$, whereas storage at $18{ }^{\circ} \mathrm{C}$ for the same period resulted in approximately $30 \%$ loss of activity. The 3-cyanopyridinase activity in extracts had a pH optimum of 8.0 with approximately $80 \%$ of maximal activity at $\mathrm{pH} 7 \cdot 0$ and $9 \cdot 0$.

HPLC analysis of the products of 3-cyanopyridine hydrolysis by a cell-free extract confirmed that the nitrile was hydrolysed to nicotinic acid plus ammonia (Fig. 3). A small quantity of a compound with a HPLC retention time corresponding to nicotinamide also accumulated. If the compound was nicotinamide it represented approximately $10 \%$ of the 3-cyanopyridine hydrolysed.

Ammonia was released from nicotinamide much more slowly than from 3-cyanopyridine, indicating that the 3-cyanopyridine degraded by the cell-free extracts was substantially hydrolysed to nicotinic acid without the formation of a free amide intermediate. This supports the conclusion from experiments with intact bacteria that probably only one enzyme, a nitrilase, was required for the conversion of 3-cyanopyridine to nicotinic acid. Hook \& Robinson (1964) found that a purified ricinine nitrilase from a Pseudomonas sp. converted the nitrile group of ricinine (a naturally occurring cyanopyridine) principally to the corresponding carboxyl group, but that $9 \%$ of the substrate was converted to the corresponding amide; this amide was not a substrate for the enzyme. In $N$. rhodochrous LL100-21, an enzyme which converts 3cyanopyridine to nicotinic acid could operate by a similar mechanism which would account for the formation of the small amount of nicotinamide during the hydrolysis of 3-cyanopyridine by cell-free extracts.

In general, cold-sensitive enzymes are oligomeric proteins and cold sensitivity is correlated with dissociation into smaller units (Bock \& Frieden, 1978). The 3-cyanopyridinase of $N$. rhodochrous LL100-21 may therefore be an oligomeric protein like the benzonitrilase of Nocardia 
sp. NCIB 11216, which was reported by Harper (1977a) to be a twelve subunit oligomeric protein that was inactive when dissociated.

\section{Suitability of $N$. rhodochrous LL100-21 for use as a biocatalyst for the production of nicotinic acid from 3-cyanopyridine}

The ability to degrade pyridine monocarboxylic acids has been found in several microorganisms, and pathways involving hydroxylation followed by oxygenative ring cleavage have been characterized (Shukla, 1984). However, nicotinic acid was not oxidized or oxidized at only an extremely slow rate by harvested $N$. rhodochrous LL100-21 bacteria that had been grown on 3cyanopyridine or nicotinamide as the nitrogen source. Nicotinic acid produced in growing cultures was not shown to be further metabolized although a very small amount could have been utilized for synthesis of NAD(P). These observations are consistent with the inability of the organism to utilize pyridine carboxylic acids for growth. Since intact $N$. rhodochrous LL100-21 can convert 3-cyanopyridine to nicotinic acid plus ammonia without further metabolism of the carboxylic acid product, the organism may be a suitable candidate for use as a biocatalyst for the production of nicotinic acid from the nitrile. This possibility has been explored further and the results will be published shortly.

This work was supported by a Science and Engineering Research Council CASE Studentship to P.A.V., in collaboration with Tate and Lyle Group Research and Development, Reading, UK.

\section{REFERENCES}

BaUCHOP, T. \& ELSDEN, S. R. (1960). The growth of micro-organisms in relation to their energy supply. Journal of General Microbiology 23, 457-469.

Bock, P. E. \& Frieden, C. (1978). Another look at the cold lability of enzymes. Trends in Biochemical Sciences 3, 100-103.

Chamberlin, P. \& Mackenzie, R. M. (1981). Enzymic hydrolysis of nitriles. In Cyanide in Biology, pp. 335-348. Edited by B. Vennesland, E. E. Conn, C. J. Knowles, J. Westley \& F. Wissing. London \& New York: Academic Press.

Clarke, P. H. (1980). The utilization of amides by microorganisms. In Microorganisms and Nitrogen Sources, pp. 537-562. Edited by J. W. Payne. New York: John Wiley.

Collins, P. A. \& Knowles, C. J. (1983). The utilization of nitriles and amides by Nocardia rhodochrous. Journal of General Microbiology 129, 711-718.

DiGeronimo, M. J. \& ANToine, A. D. (1976). Metabolism of acetonitrile and propionitrile by Nocardia rhodochrous LL100-21. Applied and Environmental Microbiology 31, 900-906.

FAWCETT, J. K. \& SCOTT, J. E. (1960). A rapid and precise method for the determination of urea. Journal of Clinical Pathology 13, 156-159.

Gornall, A. G., Bardawill, C. J. \& David, M. M. (1949). Determination of serum proteins by the biuret reaction. Journal of Biological Chemistry 177, 751-766.

GRIFFITH, T. W. \& LEACH, F. R. (1973). The effect of osmotic shock on vitamin transport in Escherichia coli. Archives of Biochemistry and Biophysics 159, 658663.

HARPER, D. B. (1976). Purification and properties of an unusual nitrilase from Nocardia NCIB 11216. Biochemical Society Transactions 4, 502-504.

HARPER, D. B. (1977a). Microbial metabolism of aromatic nitriles. Enzymology of $\mathrm{C}-\mathrm{N}$ cleavage by
Nocardia sp. (Rhodochrous group) NCIB 11216. Biochemical Journal 165, 309-319.

HARPER, D. B. $(1977 b)$. Fungal degradation of aromatic nitriles. Enzymology of C-N cleavage by Fusarium solani. Biochemical Journal 167, 685-692.

HARPER, D. B. (1985). Characterization of a nitrilase from Nocardia sp. (Rhodochrous group) NCIB 11215, using $p$-hydroxybenzonitrile as sole carbon source. International Journal of Biochemistry 17, 677-683.

Hook, R. H. \& Robinson, W. G. (1964). Ricinine nitrilase. II. Purification and properties. Journal of Biological Chemistry 239, 4263-4267.

Jallageas, J.-C., ARnaud, A. \& Galzy, P. (1980). Bioconversions of nitriles and their applications. Advances in Biochemical Engineering 12, 1-32.

Linton, E. A. \& KNOwLEs, C. J. (1986). Utilization of aliphatic amides and nitriles by Nocardia rhodochrous LL100-21. Journal of General Microbiology 132, 1493-1501.

MCPheat, W. L. \& Wardlaw, A. C. (1982). Inhibition of nicotinic acid and nicotinamide uptake into Bordetella pertussis by structural analogues. Journal of General Microbiology 128, 2681-2685.

McPheat, W. L., Wardlaw, A. C. \& Novotny, P. (1983). Modulation of Bordetella pertussis by nicotinic acid. Infection and Immunity 41, 516-522.

Miller, J. H. (1972). Experiments in Molecular Genetics, p. 431. Cold Spring Harbor, New York: Cold Spring Harbor Laboratory.

Miller, J. M. \& KNowles, C. J. (1984). The cellular location of nitrilase and amidase enzymes of Brevibacterium R312. FEMS Microbiology Letters 21, 147151.

SHUKLA, O. P. (1984). Microbial transformation of pyridine derivatives. Journal of Scientific and Industrial Research 43, 98-116.

Yamada, H., Asano, Y., Hino, T. \& TANi, Y. (1979). Microbial utilization of acrylonitrile. Journal of Fermentation Technology 57, 8-14. 